\title{
Suspension of EU Funds Paid to Member States Breaching the Rule of Law: Is the Commission's Proposal Legal?
}

\author{
Justyna Łacny
}

\section{Contents}

1 Introduction

2 Conditionality Mechanism in EU Law ................................... 271

2.1 The Conditionality Mechanism in EU Internal and External Relations .......... 271

2.2 The Financial Conditionality Mechanisms in EU Secondary Law on EU Funds ... 272

3 The Conditionality Mechanism Applied for Breaches of the Rule of Law ............. 274

3.1 The Notion of 'the Rule of Law' .................................. 275

3.2 The Notion 'Generalised Deficiency As Regards the Rule of Law in a Member State' ......................................................... 275

3.2.1 The Principle of Sound Financial Management (Article 317 TFEU) ...... 276

3.2.2 Protection of the Financial Interests of the Union (Article 325 TFEU) .... 277

3.2.3 Types of Generalised Deficiency As Regards the Rule of Law .......... 278

4 Measures Applied Under the Conditionality Mechanism ......................... 280

5 The Procedure for Adoption of a Decision Applying the Conditionality Mechanism .... 283

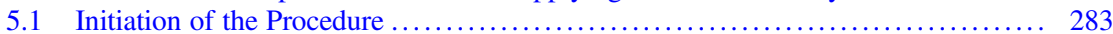

5.2 Who Adopts the Decision? ........................................ 284

5.3 Voting in the Council by Reverse QMV ............................ 285

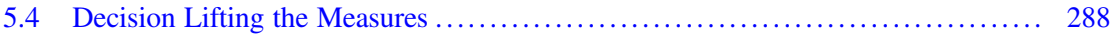

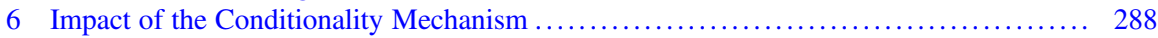

6.1 Impact of the Conditionality Mechanism on the Member States ............... 289

6.2 Impact of the Conditionality Mechanism on the Beneficiaries of EU Funds ....... 290

6.3 Impact of the Conditionality Mechanism on Relations Between the National Authorities .................................................... 292

7 The Conditionality Mechanism and Other Rule-of-Law Mechanisms ................ 293

$7.1 \quad$ The Article 7 TEU Procedure ........................................ 293

7.2 The General Infringement Procedure (Arts. 258-260 TFEU) .................. 296

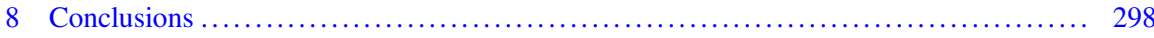

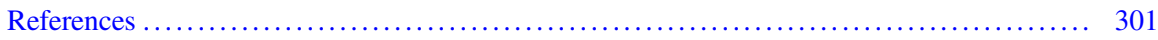

This chapter is a result of the research project No 2019/35/B/HS5/01024 financed by the National Science Centre, Poland.

\footnotetext{
J. Łacny $(\square)$

Department of Administration and Social Sciences, Warsaw University of Technology, Warsaw, Poland

e-mail: justyna.lacny@pw.edu.pl
} 


\begin{abstract}
The existing scale of violations of the rule of law by some Member States, including capturing judicial independence by their governments, is a relatively new phenomenon for the EU; the one for which the EU based on the EU common values (Article 2 TEU) originally was not prepared to effectively deal with. The EU reacts to current rule of law crisis by using different legal methods and instruments: it inter alia applies existing procedures (Article 7 TEU procedure and with more success general infringement procedure under Articles 258-260 TFEU) and struggles to develop new ones. This contribution is focused on the new EU legislative initiative of connecting in the Multiannual Financial Framework (MFF) 2021-2027 transfers of EU funds to Member States with their observance of the rule of law. Or to put it differently, this legislative initiatives would authorize the EU institutions to suspend regular transfers of EU funds to Member States that systematically breach the rule of law.
\end{abstract}

\title{
1 Introduction
}

Although in many people's views the EU was established to achieve individual and common interests of the Member States, it would be over simplistic to recognise the EU only as the community of interests. The EU is, if not primarily, the community of values such as human dignity, freedom, democracy, equality, the rule of law and respect for human rights (Article 2 TEU). If these values are put at risk or violated and the mutual trust among the Member States is hence infringed, possibilities of identifying and accomplishing common European interests are weakened. This may undermine legitimacy and rationality of the whole 'European project'. Therefore the protection of the common European values (Article 2 TEU) lies at the heart of the EU integration process.

This chapter presents the latest Commission's proposal aimed to ensure the Member States' respect of the rule of law-one of the common values on which the EU is based. The Commission intends to make regular transfers of EU funds to Member States paid from the EU budget for the implementation of different EU policies (mainly the agriculture and the cohesion policies) conditional upon their respect of the rule of law (known as 'the conditionality mechanism'). This contribution comments on the Draft Regulation as first proposed by the Commission (hereinafter: Commission version ${ }^{1}$ ) and amended during the first reading by the European Parliament (hereinafter: European Parliament version ${ }^{2}$ ). This mechanism

\footnotetext{
${ }^{1}$ Proposal for a regulation of the European Parliament and of the Council on the protection of the Union budget in the event of generalized gaps in the rule of law in the Member States $(\operatorname{COM}(2018)$ 324 final). See Halmai (2018).

${ }^{2}$ European Parliament legislative resolution of 4 April 2019 on the proposal for a regulation of the European Parliament and of the Council on the protection of the Union's budget in case of generalised deficiencies as regards the rule of law in the Member States (COM(2018) 324 final).
} 
toward Member States and relations between this mechanism and other EU Treaties procedures aimed at stopping breaches of the rule of law (the Article 7 TEU procedure) and the general infringements procedure (Article 258-260 TFEU).

\section{Conditionality Mechanism in EU Law}

\subsection{The Conditionality Mechanism in EU Internal and External Relations}

The conditionality mechanism is an EU policy tool which has been in use since the late 1980s. ${ }^{3}$ It is based on the assumption that the Member States and third countries are prompted to comply with requirements established under EU law in return for the advantages obtained. Or in other words, they would adhere to EU law due to the risk of losing advantages, particularly financial ones.

Initially, the conditionality mechanism was applied in the EU's external relations, in international agreements in which the EU made the granting of humanitarian aid to third countries conditional upon their respect for human rights. ${ }^{4}$ It continues to be so applied at present. To give some examples. If countries participating in the European Neighbourhood Policy ${ }^{5}$ implement actions agreed upon with the EU, in return they receive financial assistance and the trade and visa facilitation from the EU. ${ }^{6}$ As another example, if candidate countries want to join the EU, they must have institutions which guarantee a stable democracy, the rule of law, respect for human and minority rights as well as market economy allowing the national producers to cope with competitive pressure and market forces within the EU (the so called 'Copenhagen criteria').

Increasingly, the conditionality mechanism is being used in the EU's internal relations as well, in legal acts governing relations between the EU and its Member States. For example, the macroeconomic conditionality mechanism was introduced in 1994 to support the establishment of the European Monetary Union. It conditioned access of the less developed Member States (then Greece, Ireland, Spain and Portugal) to the Cohesion Fund on the adoption by these States of economic convergence plans and their compliance with the EU budgetary deficit rules. It has

\footnotetext{
${ }^{3}$ For more on the concept of the conditionality see: Vita (2017).

${ }^{4}$ Fierro (2003), Bartels (2005), McKenzie and Meissner (2017) and Cornelius (2016).

${ }^{5}$ Through its European Neighbourhood Policy, the EU works with its southern and eastern neighbours to foster stabilisation, security and prosperity, in line with the Global Strategy for the EU Foreign and Security Policy. See: https://eeas.europa.eu/diplomatic-network/europeanneighbourhood-policy-enp/330/european-neighbourhood-policy-enp_en; Joint Communication to the European Parliament, the Council, the European Economic and Social Committee and the Committee of the Regions, A review of the European Neighborhood Policy (JOIN (2015) 50 final). ${ }^{6}$ Council Implementing Decision 2012/156/EU of 13 March 2012 suspending commitments from the Cohesion Fund for Hungary with effect from 1 January 2013, OJ L 78/19.
} 
been enforced only once, against Hungary in 2011, albeit without leading to an actual cut-off in funding. ${ }^{7}$ As another example, in order to address the 2008 financial crisis in the EU and support those Member States with major budgetary difficulties, the EU made the financial assistance granted to them conditional on their compliance with the macro-economic convergence criteria. ${ }^{8}$

It has been observed that the increasing use of the conditionality mechanism in the EU's internal relations marks a shift towards a generalised 'conditionality culture' in the relationship between the EU and its Member States. The compliance function that the conditionality mechanism was aimed to ensure in the EU's external relations was-in the EU's internal relations-initially supposed to be fulfilled primarily by the principle of sincere cooperation between the EU and the Member States. ${ }^{9}$ If a Member State breaches its EU obligation(s), the principle of sincere cooperation does not allow the EU institutions themselves or other Member States to deprive the State in breach of its EU benefits; however the Commission or another Member State can take the case against this State to the CJEU, and as a last resort financial sanctions may be imposed on the breaching State. ${ }^{10}$ Based on this principle, the compliant Member States must continue to comply with their EU obligations, even if others do not. It has been observed that the shift from the principle of loyal cooperation to the conditionality mechanism in the EU's internal relations was brought about by the 2004 enlargement, with its attendant concerns that some 'new' Member States might decline to fulfil their EU obligations. ${ }^{11}$ Calls for the establishment of the conditionality mechanism, allowing for the suspension of EU funding to Member States breaching the rule of law (discussed further on in this chapter), may be considered as proof that these concerns related with 'new' Member States were correct. That could mean that we are heading toward a new era of conditionality in the EU.

\subsection{The Financial Conditionality Mechanisms in EU Secondary Law on EU Funds}

In the debate on the Draft Regulation introducing a new conditionality mechanism to EU law it is rightly noted that there already exists a legal basis that the Commission could apply to suspend transfers of EU funds to Member States violating the rule of law. ${ }^{12}$ It has been claimed that such an opportunity is provided by the Common

\footnotetext{
${ }^{7}$ Council Implementing Decision 2012/156/EU of 13 March 2012 suspending commitments from the Cohesion Fund for Hungary with effect from 1 January 2013, OJ L 78/19.

${ }^{8}$ Atik (2016) and Louis (2010).

${ }^{9}$ Article 4 (3) TEU.

${ }^{10}$ Article 258-260 TFEU.

${ }^{11}$ Cremona (2005).

${ }^{12}$ Butler (2018), Scheppele et al. (2018) and Kelemen and Scheppele (2018).
} 
Provisions Regulation (hereafter: CP Regulation) ${ }^{13}$ containing rules on spending the European Structural and Investment Funds (hereafter: ESIF) which finance implementation of the cohesion policy in the Member States. Similar rules also allow for the suspension of EU funds transferred to Member States for implementation of Common Agricultural Policy (CAP). ${ }^{14}$

Under the CP Regulation, the Member States spending ESIF must establish a management and control system and ensure its effective functioning. ${ }^{15}$ This system is comprised of the bodies designated by the Member States (e.g. the managing authorities, audit institutions), tasks they carry out in relation to EU funds (e.g. carrying out controls, making payments, imposing sanctions) and tools allowing for proper management and control of EU funds (e.g. databases, computer systems). This system should guarantee that these funds are spent in the Member States in accordance with EU law and that the risk of their losses is minimised. If the Commission finds a serious deficiency in the effective functioning of the management and control system in the Member State, which has put at risk the EU funds, it is authorised to suspend the payments of these funds transferred to this State. ${ }^{16}$ It may also recover them ${ }^{17}$ by imposing financial corrections on this State which leads to definitive loss of the amount of the EU funds imposed as corrections. It is claimed in the EU legal doctrine that systemic violations of the rule of law by a Member State, e.g. undermining of judicial independence, can be classified as a serious deficiency in the effective functioning of the management and control system in such State. In such a case, the Commission could suspend the EU funds transferred to this State, or recover them by imposing financial correction on this State. So far, the Commission has not explored either of these possibilities. ${ }^{18}$

Another example provided by the CP Regulation relates to the national system of legal complaints. Under this Regulation, the Member States must ensure they have effective arrangements for the examination of complaints concerning the EU funds. ${ }^{19}$ They thus must ensure the access of natural and legal persons to remedies

\footnotetext{
${ }^{13}$ Articles 23-24 Regulation No 1303/2013 of the European Parliament and of the Council of 17.12.2013 laying down common provisions on the European Regional Development Fund, the European Social Fund, the Cohesion Fund, the European Agricultural Fund for Rural Development and the European Maritime and Fisheries Fund and laying down general provisions on the European Regional Development Fund, the European Social Fund, the Cohesion Fund and the European Maritime and Fisheries Fund and repealing Council Regulation (EC) No 1083/2006 (OJ L 347, 20.12.2013, p. 320).

${ }^{14}$ Article 58 (2) Regulation No 1306/2013 of the European Parliament and of the Council of 17 December 2013 on the financing, management and monitoring of the common agricultural policy and repealing Council Regulations (EEC) No 352/78, (EC) No 165/94, (EC) No 2799/98, (EC) No 814/2000, (EC) No 1290/2005 and (EC) No 485/2008 (OJ L 347, 20.12.2013, p. 549).

${ }^{15}$ Articles 72-74 and Article 122 (1) CP Regulation. The same concerns the agricultural spending, see: Article 58 (2) 2 and Articles 67-73 Regulation No 1306/2013.

${ }^{16}$ Article 142 (a) CP Regulation.

${ }^{17}$ Article 144 (1) (a) CP Regulation.

${ }^{18}$ Kelemen and Scheppele (2018).

${ }^{19}$ Article 74 (3) CP Regulation.
} 
allowing effective legal protection in cases concerning these funds, including access to independent and impartial tribunals. ${ }^{20}$ For a Member State with an established record of breaching the rule of law, including capturing an independent prosecution and judiciary, it could be difficult to prove that it fulfils this requirement.

So far the Commission has not applied the possibilities offered by the $\mathrm{CP}$ Regulation to try to influence on Member States breaching the rule of law. Therefore, the real problem may be not the lack of adequate legal tools, but the lack of political will on the part of the Commission to use the tools that already exist. Instead, the Commission has proposed the Draft Regulation establishing the conditionality mechanism which is commented on in this chapter.

\section{The Conditionality Mechanism Applied for Breaches of the Rule of Law}

The EU is a community of law and its values constitute the very basis of its existence. Respect for these values must be ensured throughout all EU policies, including the EU budget. ${ }^{21}$ Having this in mind the Commission presented the Draft Regulation to respond to the common diagnosis that the EU lacks effective legal instruments to stop systemic breaches of the rule of law by Member States. ${ }^{22}$ It claimed that it cannot be accepted any longer and that these breaches damage the financial interests of the EU. ${ }^{23}$ Some authors point out a paradox: that the EU transfers the largest amounts of EU funds to governments of the Member States with a history of long-standing violations of the rule of law, ${ }^{24}$ for example to

\footnotetext{
${ }^{20}$ Article 19(1) TEU and Article 47 of the Charter of Fundamental Rights. See: CJEU, Case C-562/ 12, Liivimaa Lihaveis MTÜ, ECLI:EU:C:2014:2229, paras 67-75.

${ }^{21}$ Communication from the Commission. A new, modern Multiannual Financial Framework for a European Union that delivers efficiently on its priorities post-2020. COM(2018) 98 final.

${ }^{22}$ Closa and Kochenov (2016), Jakab and Kochenov (2017), Schroeder (2016), Hatje (2018), Costa (2017) and Konstadinides (2017).

${ }^{23}$ The Commission based the Draft Regulation on Article 322 (1) (a) TFEU which authorises the European Parliament and the Council to adopt regulations containing financial rules determining inter alia procedures for establishing and implementing the EU budget. This Article is commonly applied as a legal basis for adopting Financial Regulations-the main EU secondary budgetary law (presently binding Financial Regulation no 2018/1046). Selection of this legal basis could indicate that the Commission finds the conditionality mechanism as an instrument ensuring sound implementation of the EU budget (Article 317 TFEU). This is, however, in contradiction with the overall assumption expressed in the Draft Regulation that its primary objective is to protect the financial interests of the EU against damages resulting from the breaches of the rule of law by the Member States. Protection of these interests would require that the Draft Regulation would be adopted based on Article 325 (4) TFEU. Under both articles (Article 322 (1) (a) TFEU and Article 325 (4) TFEU) legal acts are adopted by the European Parliament and the Council in accordance with the ordinary legislative procedure after consulting the Court of Auditors.

${ }^{24}$ Kelemen and Scheppele (2018) and Peel et al. (2019).
} 
Poland-the largest overall recipient taking in 86 billion EUR from various ESIF in the Multiannual Financial Framework (MFF) 2014-2020; and Hungary-the largest recipient of EU funds on a per capita basis, with more than $95 \%$ of all public investment in MFF 2014-2020 having been co-financed by the EU. ${ }^{25}$ The conditionality mechanism proposed to be introduced by the Draft Regulation is supposed to remedy this situation. Before discussing this, it is necessary to engage in some terminological explanations.

\subsection{The Notion of 'the Rule of Law'}

Understandably, the key notion 'the rule of law' was defined in the Draft Regulation with regard to the Union values enshrined in Article 2 TEU. ${ }^{26}$ They include the principles of legality, implying a transparent, accountable, democratic and pluralistic process for enacting laws; legal certainty; a prohibition of arbitrariness of executive powers; effective judicial protection by independent courts, including protection of fundamental rights; separation of powers; and equality before the law. On top of this the European Parliament proposed to include the 'Copenhagen criteria' in this notion, which candidate countries must fulfil in order to accede to the EU. They include, beyond the rule of law, the stability of the institutions guaranteeing democracy, respect for and protection of human rights and minorities, and further a functioning market economy and the capacity to cope with the competition and market forces, as well as the ability to meet the obligations of Union membership. ${ }^{27}$

\subsection{The Notion 'Generalised Deficiency As Regards the Rule of Law in a Member State'}

A key notion of the Draft Regulation is 'the generalised deficiency as regards the rule of law in a Member State'. ${ }^{28}$ Detection of such a deficiency in a Member State is a necessary premise to apply the conditionality mechanism to this State.

A generalised deficiency as regards the rule of law in a Member State is defined as a widespread or recurrent practice or omission, or a measure by public authorities which violates the rule of law and affects or risks affecting the principle of sound

\footnotetext{
${ }^{25}$ It has been noted that the situations of Poland and Hungary differ, since there are no well-proven cases that breaches of the rule of law by the Polish authorities have led to the misspending of EU funds (von Brauneck 2019), while such is the case in Hungary (Kelemen and Scheppele 2018) and Romania (Pech et al. 2019).

${ }^{26}$ Article (a) Draft Regulation (Commission proposal).

${ }^{27}$ Article 49 TEU.

${ }^{28}$ On similar notion of 'systemic deficiency as regards the rule of law' see: von Bogdandy (2019).
} 
financial management or the protection of the financial interests of the EU. ${ }^{29}$ Some clarification is necessary as regards the principle of sound financial management and the protection of the financial interests of the EU.

\subsubsection{The Principle of Sound Financial Management (Article 317 TFEU)}

The 'principle of sound financial management', as set forth in the TFEU, ${ }^{30}$ relates to the EU budget and its implementation. The Financial Regulation no 2018/1046 ${ }^{31}$ the main EU secondary budgetary law act-provides explanations on the meaning of these terms.

The EU budget forecasts and authorises for each financial year all revenue and expenditures considered necessary for the EU. Implementation of this budget requires the carrying out of activities related to the management, monitoring, control and auditing of EU appropriations, undertaken in accordance with the relevant methods of its implementation. ${ }^{32}$ The TFEU entrusts responsibility for the implementation of the EU budget to the Commission. ${ }^{33}$ The latter is obliged to implement the EU budget in cooperation with the Member States, on its own responsibility and within the limits of the appropriations, having regard to the principles of sound financial management. Member States must cooperate with the Commission during implementation of the EU budget in order to ensure that the appropriations are used in accordance with this principle. ${ }^{34}$ When the European Court of Auditors (the ECA) undertakes its core tasks and examines how the Commission implements the EU budget, it checks, inter alia, whether the financial management has been sound. ${ }^{35}$

According to Financial Regulation no $2018 / 1046,{ }^{36}$ the principle of sound financial management-one of the EU budgetary principles ${ }^{37}$ - requires that the EU budget is implemented in accordance with the principles of economy, efficiency,

\footnotetext{
${ }^{29}$ Article 2 (b) Draft Regulation.

${ }^{30}$ Article 287 (2) 2 TFEU, Article 310 (5) TFEU and Article 317 TFEU.

${ }^{31}$ Regulation (EU, Euratom) 2018/1046 of the European Parliament and of the Council of 18 July 2018 on the financial rules applicable to the general budget of the Union, amending Regulations (EU) No 1296/2013, (EU) No 1301/2013, (EU) No 1303/2013, (EU) No 1304/2013, (EU) No 1309/ 2013, (EU) No 1316/2013, (EU) No 223/2014, (EU) No 283/2014, and Decision No 541/2014/EU and repealing Regulation (EU, Euratom) No 966/2012, OJ L 193, 30.7.2018, p. 1, hereafter Financial Regulation no 2018/1046.

${ }^{32}$ Article 2 (7) Financial Regulation no 2018/1046.

${ }^{33}$ Article 310 (5) TFEU.

${ }^{34}$ Article 317 TFEU.

${ }^{35}$ Article 287 (2) TFEU.

${ }^{36}$ Article 2 (59), Article 6 and Article 33 Financial Regulation no 2018/1046.

${ }^{37}$ Next to principles of unity, budgetary accuracy, annuality, equilibrium, unit of account, universality, specification, and transparency.
} 
and effectiveness. ${ }^{38}$ The CJEU claims that the principle of sound financial management (applied in area of the EU funds) corresponds to the principles of sincere co-operation (applied in general terms of EU law ${ }^{39}$ ). The CJEU often recalls this principle in the context of EU rules establishing tasks related to the management and spending of EU funds, to underline the necessity to protect them. ${ }^{40}$

\subsubsection{Protection of the Financial Interests of the Union (Article 325 TFEU)}

The objective of the conditionality mechanism, eventually to be established by the Draft Regulation, is to protect the financial interests of the Union (the EU budget) against damages deriving from breaches of the rule of law by the Member States. This fact is stipulated in the title of this Draft (Regulation on the protection of the Union's budget) and in its provisions. ${ }^{41}$ They foresee that this Draft would establish rules necessary for the protection of the Union's budget in the case of generalised deficiencies as regards the rule of law in the Member States. ${ }^{42}$ What's more, a generalised deficiency as regards the rule of law in a Member State-a premise necessary to launch the conditionality mechanism-was defined as a common national practice violating the rule of law and affecting or risking to affect the protection of the financial interests of the $\mathrm{EU}{ }^{43}$

\footnotetext{
${ }^{38}$ The principle of economy stipulates that the resources used by the EU institutions concerned in the pursuit of its activities are made available in due time, in appropriate quantity and quality, and at the best price. The principle of efficiency concerns the best relationship between the resources employed, the activities undertaken and the achievement of objectives. The principle of effectiveness concerns the extent to which the objectives pursued are achieved through the activities undertaken.

${ }^{39}$ Article 4 (3) TEU.

${ }^{40} \mathrm{CJEU}$, Cases C-138/03, C-324/03 and C-431/03 Italy v. Commission, ECLI:EU:C:2005:714, para. 44; CFI, Case T-345/03 Evropaïki Dynamiki v. Commission, ECLI:EU:T:2015:168, para. 77; CFI, Case T-549/08 Luxemburg v. Commission, ECLI:EU:T:2010:244, para. 47; Court, Case T-265/08 Germany v. Commission, ECLI:EU:T:2012:434, para. 40; CJEU, Case C-500/99 $P$ Conserve Italia v. Commission, ECLI:EU:C:2002:45, para. 88; CFI, Case T-308/05, Italy v. Commission, ECLI:EU:T:2007:382, para. 109; opinion of AG Trstenjak, Case C-539/09 Germany v. Commission, ECLI:EU:C:2011:345, para. 95.

${ }^{41}$ See also paras 9-11, opinion of the Court of Auditors No 1/2018 concerning the proposal of 2 May 2018 for a regulation of the European Parliament and of the Council on the protection of the Union's budget in case of generalised deficiencies as regards the rule of law in the Member States, hereafter: ECA opinion No 1/2018.

${ }^{42}$ Article 1 Draft Regulation.

${ }^{43}$ Article2 (b) Draft Regulation.
} 
The notion 'protection of the financial interests of the Union', is used in the TFEU, ${ }^{44}$ defined in EU secondary law, ${ }^{45}$ and clarified by the CJEU. ${ }^{46}$ The 'financial interests of the Union' encompass revenues, expenditures, and assets covered by the EU budgets, the budgets of the EU institutions, bodies, offices and agencies established under the EU Treaties, and budgets directly or indirectly managed and monitored by them. Article 325 TFEU, the main Treaty provision regarding financial interests of the Union, obliges the Member States and the EU institutions to counter fraud and any other illegal activities affecting these interests through deterrent measures that should ensure their effective protection. In turn, the Member State on their side should take the same measures to counter fraud affecting the financial interests of the EU as they take to counter fraud affecting their own financial interests (the assimilation principle).

To sum up, a generalised deficiency as regards the rule of law, the existence of which in a Member State is a necessary premise of launching the conditionality mechanism, indicates (1) a common conduct on the part of public authorities of the Member States that (2) violate the rule of law, which (3) adversely affects or is likely to affect the EU funds (the financial interests of EU, Article 325 TFEU) or its management (the sound financial management of the EU, Article 317 TFEU).

\subsubsection{Types of Generalised Deficiency As Regards the Rule of Law}

Presented definition of 'a generalised deficiency as regards the rule of law' was formulated broadly-worded. To give some examples of these generalised deficiencies and to limit the scope of interpretation of this notion at the same time, the Commission and the European Parliament established their specific types.

The Commission provided for two lists of generalised deficiency as regards the rule of law. The first list includes, generally speaking, the conduct of national authorities (administrative, investigative, and judicial) related to EU funds. The list is left open. Deficiencies included there do not have to be serious, since they include, e.g., practices on the part of a national authority affecting the effective and timely cooperation with the European Anti-Fraud Office (OLAF) or the European Public Prosecutor's Office. ${ }^{47}$ Detection of these types of deficiencies as regards the rule of law in the Member States leads $t^{48}$ the launching of a conditionality mechanism. In contrast, the second list of generalised deficiencies as regards the rule of law indicates conducts on the part of national administration that may lead ${ }^{49}$ to the initiation of the conditionality mechanism. In this case the deficiencies are related

\footnotetext{
${ }^{44}$ Article 310 (5) and Article 325 TFEU.

${ }^{45}$ Article (1) (a) Directive (EU) 2017/1371.

${ }^{46}$ Opinion of AG Jacobs in Case C-11/00 Commission v. ECB, ECLI:EU:C:2002:556.

${ }^{47}$ Article 3 (1) (f) Draft Regulation (Commission proposal).

${ }^{48}$ Article 3 (1) Draft Regulation (Commission proposal).

${ }^{49}$ Article 3 (2) Draft Regulation (Commission proposal).
} 
merely to the national judiciary and concern its constitutional determinants (e.g. judicial independence), administration (e.g. lack of relevant financial and human resources), and actions performed (e.g. prosecuting, sanctioning). There is, however, no requirement that these deficiencies must or may affect the financial interest of the Union.

The European Parliament's approach was similar, as it also created two lists of generalised deficiencies as regards the rule of law. The first, also open list, relates to the conduct of national administration and justice and includes, e.g., failing to prevent, correct and sanction arbitrary or unlawful decisions made by public authorities; limiting the availability and effectiveness of legal remedies, including through restrictive procedural rules; lack of implementation of judgments or limiting the effective investigation, prosecution and sanctioning of breaches of law. This list includes inter alia 'endangering the administrative capacity of Member States to respect the obligations of Union membership, including the capacity to effectively implement EU law'. Last but not least, measures that weaken the protection of confidentiality of communications between lawyers and clients were also included on this list. ${ }^{50}$ The second list includes generalised deficiencies as regards the rule of law that endanger or risk to endanger financial interests of the Union. ${ }^{51}$ This list includes general deficiencies included on the Commission's first list, ${ }^{52}$ as well as two new breaches, concerning among other Copenhagen criteria ${ }^{53}$ and fundamental rights. $^{54}$

To sum up deliberation on the notion of 'a generalised deficiency as regards the rule of law' - the premises necessary to launch a conditionality mechanism, it can be said that it has been formulated extremely broadly, and its scope is virtually impossible to determine. The general wording leaves the Commission and the Council-the EU institutions that would launch the conditionality mechanismwith a wide margin of discretion, which is undesirable, especially from the point of view of the principles of legal certainty and legality of sanctions. This principle requires that any provision imposing sanctions on entities must be formulated clearly and precisely, so that they can determine with certainty the scope of their rights and

\footnotetext{
${ }^{50}$ Article 2 (a) Draft Regulation (European Parliament proposal).

${ }^{51}$ Article 3 Draft Regulation (European Parliament proposal).

${ }^{52}$ Article 3 (1) Draft Regulation (Commission proposal).

${ }^{53}$ Distortion or risk of distortion of proper functioning of the market economy and effective implementation of obligations of membership, including adherence to the aim of political, economic and monetary union could constitute generalised deficiencies as regards the rule of law (Article 3 (1) aa Draft Regulation, European Parliament proposal).

${ }^{54}$ This same classification could be given to the shortages in proper implementation of the EU budget following a systemic violation of fundamental rights (Article 3 (1) fa Draft Regulation (European Parliament proposal).
} 
obligations and take appropriate actions. ${ }^{55}$ As required by the CJEU, this principle should be rigorously observed, particularly in the case of provisions that have or may have a financial impact. Viewed in this light, it may be stated that the notion of a generalised deficiency as regards the rule of law is neither clear nor precise. Its strict formulation is even more necessary if one takes into account the oppressive nature that the conditionality mechanism may have on the Member State and beneficiaries (see Sect. 5.2). It seems highly undesirable that the EU institutions, in taking actions against Member States for breaching the rule of law, may itself frustrate this rule by applying premises which are formulated (too) broadly. The wide scope of the competences conferred on the EU institutions under the conditionality mechanism has also been criticized by the ECA, which recommended to the EU legislator to establish precise criteria defining the concept of a generalised deficiency as regards the rule of law, and to specify measures to be taken in this framework. The suggested clarifications, sharpening the Draft Regulation, could satisfy the principle of legal certainty and legality of sanctions as well as limit the scope of the EU institutions' discretion. ${ }^{56}$

\section{Measures Applied Under the Conditionality Mechanism}

The conditionality mechanism is a general term under which specific measures would be imposed on the Member States breaching the rule of law. These measures would depend on which method of implementing the EU budget is used for spending the EU funds. These methods - namely direct, shared, and indirect managementrequire different entities incurring expenditures financed from the EU budget (EU funds) to comply with related tasks and responsibilities established in EU law, and authorise the Commission to take supervisory actions to ensure their proper spending. ${ }^{57}$ These methods vary according to which entity is spending the EU funds. In the case of direct management, the funds are spent by the Commission, through its departments and executive agencies; in the case of shared management-by the Member States; and in the case of indirect management-by third countries, international organizations, and other entities. ${ }^{58}$

\footnotetext{
${ }^{55}$ CJEU Cases: 70-83, Kloppenburg, ECLI:EU:C:1984:71; 325/85, Ireland v. Commission, ECLI: EU:C:1987:546, para. 18; C-143/93, Gebroeders van Es Douane Agenten, ECLI:EU:C:1996:45, para. 27; C-177/96, Banque Indosuez, ECLI:EU:C:1997:494; C-439/01, Cipra, Kvasnicka, ECLI: EU:C:2003:31, para. 49; C-110/03, Belgium v. Commission, ECLI:EU:C:2005:223, para. 30; C-158/06, Stichting ROM-projecten, ECLI:EU:C:2007:370, paras 25-26.

${ }^{56}$ ECA opinion No 1/2018, paras 12-16, 19.

${ }^{57}$ The methods of implementation of the EU budget is determined by Financial Regulation 2018/ 104, Article 62.

${ }^{58}$ Financial Regulation 2018/1046, Article 62 (1) (c).
} 
Here we focus on shared management, ${ }^{59}$ under which the EU funds are spent for the implementation of the CAP and the cohesion policy, altogether constituting about $70 \%$ of the EU's budgetary expenditures. ${ }^{60}$ If the EU funds are spent under shared management, the following measures can be applied under the conditionality mechanism: suspension of approval of programs or amendments thereof; suspension of commitments; reduction of commitments, including through financial corrections or transfers to other spending programs; reduction of pre-financing; an interruption of payment deadlines; and suspension of payments. ${ }^{61}$

The Draft Regulation does not establish how these measures should operate in practice, nor even provide their general legal characteristics. There is also no guidance as to which types of the above-mentioned measures should be applied in the case of certain generalised deficiencies as regards the rule of law. The Draft Regulation simply refers to the names of particular measures, which may suggest the essence of the activities undertaken. Very general information is given in the preamble, which states that these measures should include the suspension of payments and of commitments, a reduction of funding under existing commitments, and a prohibition on concluding new commitments with recipients. ${ }^{62}$

The application of these measures requires recourse to the EU sectoral Regulations, which provide specific rules for the spending of the EU funds for EU policies, e.g. for the CAP and the cohesion policy. Surprisingly, the Draft Regulation does not mention such a reference. It must also be noted that, at present, a detailed and final assessment of these sectoral Regulations is not possible since they are undergoing legislative processes in the EU institutions heading the new MFF 2021-2027. ${ }^{63}$ At this point in time, it can only be stated that these measures can be taken at various stages of the implementation of EU policies: from the stage of approval of national programs by the Commission to the stage of making legal commitments by the Commission, followed by the payments of the EU funds to the Member States. It is clear however that one of these measures consists of suspending the payment of EU funds, ${ }^{64}$ and this is what the remainder of this contribution will mainly focus on.

The undefined nature of the measures to be imposed under the conditionality mechanism deserves the same criticism which was already formulated towards the

\footnotetext{
${ }^{59}$ Craig (2012), p. 27; Hofmann et al. (2012); Schöndorf-Haubold (2011).

${ }^{60}$ Communication from the Commission. A new, modern Multiannual Financial Framework for a European Union that delivers efficiently on its priorities post-2020. COM(2018) 98 final.

${ }^{61}$ Article 4 (1) (b) Draft Regulation (Commission proposal).

${ }^{62}$ Recital 13 preamble Draft Regulation (Commission proposal).

${ }^{63}$ Proposal for a Regulation of the European Parliament and of the Council on the financing, management and monitoring of the common agricultural policy and repealing Regulation (EU) No 1306/2013 (COM(2018)393 final) and proposal for a Regulation of the European Parliament and of the Council laying down common provisions on the European Regional Development Fund, the European Social Fund Plus, the Cohesion Fund, and the European Maritime and Fisheries Fund and financial rules for those and for the Asylum and Migration Fund, the Internal Security Fund and the Border Management and Visa Instrument (COM(2018)375 final).

${ }^{64}$ See point 7 ECA opinion No 1/2018.
} 
vagueness of the premise of its application, namely notion of 'a generalised deficiency as regards the rule of law' (see: Sect. 3.2 above). Principles of legal certainty and legality of sanctions must be recalled once again to evoke that any provision imposing sanctions must be formulated clearly and precisely. ${ }^{65}$ The CJEU requires that these principle should be rigorously observed, particularly in the case of provisions that have or may have a financial impact. Viewed in this light, it may be stated that neither the premise of launching the conditionality mechanism (the notion of 'a generalised deficiency as regards the rule of law') nor measures imposed under this mechanism are clear nor precise. Its strict formulation is even more necessary if one takes into account the oppressive nature that the conditionality mechanism may have on the Member State and beneficiaries (see Sect. 6).

What's important and deserves credit, the Draft Regulation provides rules which the EU institutions (the Commission or the Council) should take into account when imposing measures under the conditionality mechanism. ${ }^{66}$ They would be obliged to ensure that these measures should be proportionate to the nature, gravity, and scope of the generalised deficiency as regards the rule of law. These measures also should, insofar as possible, target the EU actions affected or potentially affected by that deficiency. The requirement of proportionality between the generalised deficiency as regards the rule of law, that is EU law infringement leading to launching of the conditionality mechanism on one side, and measures adopted under this mechanism on the other side signifies that these measures are deemed as sanctions imposed upon the Member State for breaching the rule of law. Under EU law, the principle of proportionality is the sine qua non condition of adoption of any sanctions imposed as the result of an infringement of a law.

To sum up this sub-section, the Draft Regulation provides generally-formulated premises for launching the conditionality mechanism together with their very specific examples, which can lead to measures of a really unknown (as yet) character. This extremely broad formulation of provisions defining prohibited infringements of the law and sanctions imposed for their perpetration raises concerns as to their legality. It is because it cannot be claimed that these provisions are clear and or precise, as the principles of legal certainty and legality of sanctions would require. No matter how challenging this may be, respect for the principles of legality and legal certainty would require the premises for launching the conditionality mechanism to be formulated more unequivocally. Provisions of the Draft Regulation should clearly indicate major types and a closed list of examples of systematic breaches of the rule of law that could lead to the activation of this mechanism.

\footnotetext{
${ }^{65}$ CJEU Cases: 70-83, Kloppenburg, ECLI:EU:C:1984:71; 325/85, Ireland v. Commission, ECLI: EU:C:1987:546, para. 18; C-143/93, Gebroeders van Es Douane Agenten, ECLI:EU:C:1996:45, para. 27; C-177/96, Banque Indosuez, ECLI:EU:C:1997:494; C-439/01, Cipra, Kvasnicka, ECLI: EU:C:2003:31, para. 49; C-110/03, Belgium v. Commission, ECLI:EU:C:2005:223, para. 30; C-158/06, Stichting ROM-projecten, ECLI:EU:C:2007:370, para. 25-26.

${ }^{66}$ Article 4 (3) Draft Regulation (Commission proposal) and Article 5a Draft Regulation (European Parliament proposal).
} 
These provisions should be formulated taking into account the standards established in the case-law of the CJEU and the ECtHR for the imposition of sanctions.

\section{The Procedure for Adoption of a Decision Applying the Conditionality Mechanism}

While the proposals lodged by the Commission and the European Parliament concerning premises for launching the conditionality mechanism are generally in line with each other, their proposals for procedural rules to be applied to this end differ considerably. Disparities concern the key issue, namely determining the EU institution that would adopt a decision applying the conditionality mechanism and the procedural steps that would be taken in this regard. While the Commission proposed that this decision should be adopted by the Council, on a request from the Commission, according to the European Parliament this decision should be adopted by the Commission, with a right of the European Parliament and the Council to oppose it or change it. These issues are presented below.

\subsection{Initiation of the Procedure}

According to the Draft Regulation, initiation of the conditionality mechanism would require a determination that there is at least one generalised deficiency as regards the rule of law in the Member State targeted (see Sect. 3.2).

The Commission proposes that it would conduct an inquiry by itself and that if it found a generalised deficiency, it would indicate it in a written notification submitted to the Member State concerned. The Commission could request additional information from this State, including proposals for remedial measures. The Member State would have to provide the Commission with information within the time-limits set by the Commission, not less than 1 month from the date of the written notification. When assessing the existence of a generalised deficiency as regards the rule of law, the Commission could take into account all information, including judgments of the CJEU, reports of the ECA, and recommendations of international organizations. ${ }^{67}$

The European Parliament has proposed two modifications to this procedure. The first concerned the establishment of an advisory panel of independent experts (hereafter: Panel) that would assist the Commission in assessing the existence of a generalised deficiency as regards the rule of law in a given Member State. The second one concerns obliging the Commission to take into account certain Copenhagen criteria while making such an assessment.

${ }^{67}$ Article 5 Draft Regulation (Commission proposal). 
The primary function of the Panel would be to assist the Commission in identifying generalised deficiencies as regards the rule of law in the Member States. ${ }^{68}$ This function would be achieved in a twofold manner. Firstly, the Panel would adopt $a d$ hoc opinions concerning generalised deficiencies as regards the rule of law as examined by the Commission. Secondly, the Panel would annually assess situations in all Member States as regards their respect for the rule of law and would make a public summary of its findings each year. The Draft Regulation thus would create a new body - the Panel—entrusted with the task of continuous monitoring of the rule of law situation in all the Member States.

As regards the Copenhagen criteria, the European Parliament proposes that the Commission should examine them when assessing the existence of generalised deficiencies as regards the rule of law in a Member State. The criteria should include: chapters of the aquis on judiciary and fundamental rights, justice, freedom and security; financial control and taxation; as well as guidelines used in the context of the Cooperation and Verification Mechanism (CVM). ${ }^{69}$ The idea to link the compliance with the rule of law with the Copenhagen criteria may raise concerns. It is not evident why and how the compliance of the Member States with the legal principle (the rule of law) could be assessed by evaluation of political criteria, in some cases not even substantially related with the rule of law (e.g. financial control and taxation).

\subsection{Who Adopts the Decision?}

The subsequent action, after the Commission finds a generalised deficiency as regards the rule of law in the Member State, consists of the adoption of a decision launching the conditionality mechanism (see Sect. 4). The Commission's and the European Parliament's proposals considerably differ as to who should adopt this decision.

\footnotetext{
${ }^{68}$ The Panel would be established by the Commission from specialists of constitutional law and financial and budgetary matters. Each national parliament of the Member States would nominate one expert to this Panel and the European Parliament would appoint five experts. Representatives of relevant organisations and networks could be invited to the Panel as observers. Article 3a Draft Regulation (European Parliament proposal).

${ }^{69} \mathrm{CVM}$ is a transitional measure established by the Commission to assist Romania and Bulgaria in progress after their accession to the Union in the fields of judicial reform, corruption and organised crime. The Commission assesses progress under CVM based on benchmarks established for each State. The benchmarks for Romania concern effectiveness and transparency of the judicial system and the fight against and prevention of corruption. The benchmarks for Bulgaria deal with the independence, professionalism, and efficiency of the judicial system and the fight against corruption and organised crime. The Commission reports on developments on a regular basis. For more, see: https://ec.europa.eu/info/policies/justice-and-fundamental-rights/upholding-rule-law/rule-law/assis tance-bulgaria-and-romania-under-cvm/cooperation-and-verification-mechanism-bulgaria-andromania_en.
} 
The Commission proposes that if it detects a generalised deficiency as regards the rule of law in a Member State, it would submit to the Council a proposal for a decision imposing measures on this State, e.g. suspending its payments from the EU funds. ${ }^{70}$ This decision would be deemed to have been adopted unless the Council rejects it by a QMV within 1 month of the Commission's submission of its decision. ${ }^{71}$ The Council may also amend this proposal by a QMV, with no time limits established for amendment.

The European Parliament proposal differs, as it foresees the adoption of two decisions, both by the Commission. In the first decision, addressed to the Member State concerned, the Commission indicates a measure to be imposed on this State under the conditionality mechanism (e.g. suspension of EU funds). In the second decision, addressed to the European Parliament and to the Council (the EU budgetary authorities), the Commission indicates an amount equivalent as a measure adopted in the first decision (e.g. amount of EU funds suspended). Then this amount is classified as a EU budgetary reserve. The idea to adopt the latter decision, regulating the legal and financial status of the amount concerned under the conditionality mechanism, fills the gap in the Commission proposal, which would not determine what would in legal terms happen to these funds. Both decisions are considered to be adopted unless the European Parliament (acting by majority of the votes cast) or the Council (acting by QMV), amend or reject it within 4 weeks of its receipt. ${ }^{72}$

\subsection{Voting in the Council by Reverse QMV}

The procedure to be followed by the EU institutions to adopt a decision launching the conditionality mechanism is peculiar and therefore deserves attention. This decision is not adopted under the standard legislative procedures provided by the EU Treaties (most commonly applied-the ordinary and special legislative procedures $^{73}$ ), but under a peculiar procedure created by the Draft Regulation. The same concerns the voting cast in the Council. The Council would not vote on this decision by the simple majority votes or by the ordinary QMV, the latter being the standard cast provided for the Council's voting by the EU Treaties, ${ }^{74}$ but by reverse QMV—not foreseen by the EU Treaties.

\footnotetext{
${ }^{70}$ Article 5 (6-8) Draft Regulation (Commission proposal).

${ }^{71}$ The Council votes on the Commission's proposal by reverse QMV. For more on this, see Sect. 5.3 below.

${ }^{72}$ Article 5 (6 a) (6 b) (6 c) Draft Regulation (European Parliament proposal).

${ }^{73}$ Articles 289 and 294 TFEU.

${ }^{74}$ Qualified majority votes is the 'standard' voting method in the Council used when the Council takes decisions during the ordinary legislative procedure. About $80 \%$ of all EU legislation is adopted with this procedure. A qualified majority is reached in the Council if 55\% of Member States vote in favour (16 out of 28 ) and the proposal is supported by the Member States representing at least $65 \%$ of the total EU population. The blocking minority includes at least four Council members representing more than $35 \%$ of the EU population (Article 238 TFEU).
} 
In general, when the Council votes by the ordinary QMV, obtaining this majority leads to the adoption of a legal act. In the case of voting by reverse QMV the logic is different - a proposal submitted by an applicant (in our case-the Commission) is adopted unless the legislator (the Council) rejects or amends it acting by standard QMV in a vote held in a given period. Following this period, a decision is considered adopted. Thus, in the case of reverse QMV - a failure to obtain the standard QMV necessary to block or change a proposal results in its adoption (in the wording of the Draft Regulation 'the decision shall be deemed to have been adopted'), while this majority is necessary to reject or amend it. Under reverse QMV abstention counts as positive votes, forcing the Member States to take a clear position and obliging them to explicitly vote against the proposal, rather than following a more politically expedient route of abstaining.

It can therefore be concluded that if the Commission sought to suspend EU funds to a Member State for breaching the rule of law, but it was not convinced of the Council's support, it would much easier achieve its intention under the reverse QMV then under the ordinary QMV. This is because in the case of voting by reverse QMV the decision would only require that the Council would not reject it by ordinary QMV (within 1 month) or otherwise amend it by such QMV. So, if there is no ordinary QMV to reject (within 1 month) or amend the decision, it would be adopted. In contrast, if this decision would be voted by ordinary QMV, to be adopted, it would have to be approved by ordinary QMV.

According to the Commission, the idea that the Council would vote on a decision launching the conditionality mechanism by reverse QMV is dictated by the necessity to protect the financial interests of the Union (in short-the EU funds). ${ }^{75}$ It seems rather unthinkable to claim that necessity to protect the EU funds requires circumvention of the EU legislative procedure. It is not the first time in history of the EU when voting in the Council by reverse QMV is to be introduced as a remedy allowing an effective implementation of the EU policies. Such voting was already established in 2011 when rules aimed to strengthen effective enforcement of the EU fiscal policy were agreed. Under EU fiscal rules (Article $126 \mathrm{TFEU}$ ), the euro area Member States must avoid excessive government deficit (3\% of GDP), debt (60\% of GDP) and maintain sound and sustainable public finance. The Stability and Growth Pact (the SGP) was signed by all Member States based on Articles 121 and 126 TFEU to facilitate and maintain these rules. The SGP provides for fiscal monitoring of the Member States' budgetary situation by the Commission and the Council. It purpose was to ensure that the Member States maintain and enforce EU fiscal rules and do not exceed budgetary deficit and debt limits. Under the SGP ('preventive arm') each year all Member States submit a compliance report presenting expected fiscal development for the current and subsequent 3 years ('stability programmes' for eurozone Member States and 'convergence programmes' for non-eurozone Member States). If a Member State does not comply with the EU fiscal rules, an 'Excessive Deficit Procedure' (EDP) is initiated under the SGP

\footnotetext{
${ }^{75}$ Recital 15 preamble Draft Regulation. See critics: ECA opinion No 1/2018, para. 12.
} 
('dissuasive arm'). If this situation continues to remain despite multiple warnings, sanctions can be imposed on this Member State. In 2011, in the face of the world financial crisis, enforcement of the SGP was strengthened by the adoption of 'Six Pack', 'Two Pack' and 'Fiscal Compact'. These acts provided for automaticity of sanctions, including interest-bearing deposits, non-interest-bearing deposits and fines to be imposed on the Member States for recurrent breaches of the EU fiscal rules. ${ }^{76}$ These sanctions are imposed based on the reverse QMV in the Council. The Commission can impose them unless the Council decides by the reverse QMV to reject the Commission recommendation within a specified period (usually 10 days). Adoption of these sanctions thus requires a minority of the Member States to agree on the Commission proposal or alternatively an ordinary QMV to block or change this proposal. ${ }^{77}$ Legality of imposing sanctions on the Member States by voting in the Council by the reverse QMV was not contested in action brought before the CJEU. Therefore the position of the CJEU on this issue is unknown.

Coming back to the conditionality mechanism, it can be stated that the logic applied in 2011 in the 'Six Pack', 'Two Pack' and 'Fiscal Compact' in area of sanctions to be imposed for breaching - by the Member States-the EU fiscal rules established under Article 126 TFEU and the SGP was reused in 2018 in the Draft Regulation (the Commission proposal) providing for suspension of EU funds transferred to the Member States systematically breaching the rule of law. In both cases the procedural peculiarities facilitate a procedure of adopting EU secondary acts imposing sanctions on the Member States and strengthen the procedural role of the Commission vis à vis a Member State suspected to breach the EU law (the EU fiscal rules or the rule of law). Procedural peculiarities concern both the type of a legislative procedure to be followed to adopt a decision initiating the conditionality mechanism (a special procedure established by the Draft Regulation) and the necessary vote cast in the Council to adopt it (reverse QMV). As regards the legislative procedure (adoption of a decision by the Council) the EU Treaties neither provide it as one of the standard legislative procedures that the EU institutions apply to adopt EU secondary law (e.g. legislative, delegated, implementing acts and acts 'without adjective') nor authorise the EU institutions to apply it. So, the Draft Regulation establishes a legislative procedure specially for the sake of the conditionality mechanism, which remains outside of the EU Treaties regime. The same can be said about voting by the Council under the reverse QMV to adopt a decision launching the conditionality mechanism. Such a majority is not foreseen under the

\footnotetext{
${ }^{76}$ Articles 4-6 Regulation No $1173 / 2011$ of the European Parliament and of the Council of 16 November 2011 on the effective enforcement of budgetary surveillance in the euro area (OJ L 306, 23.11.2011, p. 1); Article 3 Regulation No 1174/2011 of the European Parliament and of the Council of 16 November 2011 on enforcement measures to correct excessive macroeconomic imbalances in the euro area (OJ L 306, 23.11.2011, p. 8); Article 10 (4) Regulation No 1176/ 2011 of the European Parliament and of the Council of 16 November 2011 on the prevention and correction of macroeconomic imbalances (OJ L 306, 23.11.2011, p. 25); Article 7 Treaty on Stability, Coordination and Governance in the Economic and Monetary Union (Fiscal Compact).

${ }^{77}$ Van Aken and Artige (2013), p. 131; Chalmers et al. (2015), p. 751.
} 
EU Treaties. Just to remind Article 16 (3) TEU foresees that the Council act by a standard QMV except where the Treaties provide otherwise. There is no provision under the Treaties which authorise the Council to vote under reverse QMV. These doubts inevitably lead to a question of legality of the Draft Regulation establishing procedural conditions of adopting a decision initiating the conditionality mechanism, not mentioned nor foreseen under EU Treaties.

\subsection{Decision Lifting the Measures}

The Member State against whom the conditionality mechanism was initiated is authorized at any time to provide the Commission with evidence that it has remedied or eliminated the generalised deficiency as regards the rule of law. On this base the Commission assesses the situation in this State with a view toward adopting a decision lifting the conditionality mechanism. ${ }^{78}$ This formula was presented by the Commission, and the European Parliament subsequently added two elements to it. The first is that the Commission should assess the situation in the Member State taking into account the opinion of the Panel (see Sect. 5.1) and second, that the Commission should act within 1 month and in any case within a reasonable timeframe from the date of receipt of the notification from the Member State. ${ }^{79}$

A decision lifting the conditionality mechanism would be issued by the EU institutions that have adopted it - by the Council (as the Commission proposes) or by the Commission (as the European Parliament proposes). The same procedure would apply mutatis mutandis. ${ }^{80}$

\section{Impact of the Conditionality Mechanism}

The key issue related to the conditionality mechanism concerns its real financial impact. In the public debate it is frequently claimed that its essence is a temporary suspension of transfers of EU funds to the Member State breaching the rule of law. However, analysis of the Draft Regulation reveals that this diagnosis seems overly simplistic, and launching of the conditionality mechanism may end up as well in a definitive loss of the EU funds by the Member State in question. What's more, this may also affect individuals. These issues are presented below.

\footnotetext{
${ }^{78}$ Article 6 (2) Draft Regulation (Commission proposal).

${ }^{79}$ Article 6 (2) Draft Regulation (European Parliament proposal).

${ }^{80}$ Article 6 (2) Draft Regulation (Commission proposal and European Parliament proposal).
} 


\subsection{Impact of the Conditionality Mechanism on the Member States}

According to the Draft Regulation, if EU funds are suspended under the conditionality mechanism, the amounts corresponding to the suspended commitments are re-entered into the EU budget subject to the Article 7 Draft Multiannual Financial Framework Regulation ${ }^{81}$ (the Draft MFF Regulation). Re-entering allows reallocation and future reutilisation of the EU funds in question (see Sect. 5.2). What is important, the Article 7 Draft MFF Regulation proposes that commitments suspended in year ' $n$ ' due to a generalised deficiency as regards the rule of law in a Member State may not be re-entered into the EU budget later than in the year ' $n$ ' $+2 .^{82}$ The Draft Regulation contains a similar provision, stipulating that suspended commitments for year ' $n$ ' may not be entered into the EU budget beyond year ' $n$ ' $+2 .^{83}$ On the top of this, from year ' $n$ ' +3 , amounts corresponding to the suspended commitments should be entered in the Union Reserve for Commitments (hereafter: Union Reserve). ${ }^{84}$ This Reserve is a new financial instrument which would be financed from, inter alia, funds committed to the EU budget but ultimately not spent for the implementation of EU programmes and thus de-committed. Amounts of the Union Reserve would be made available for the Member State in the new MFF 2021-2027.

In should be thus reminded that according to political declarations and its common understanding by the public, the conditionality mechanism is supposed to only lead to a temporary suspension of EU funds of the Member States breaching the rule of law, thus motivating them to eliminate the breaches promptly. If that is the case, the funds should be returned to these States. However, this may not happen because of the ' $n+2$ ' rule contained in the Draft Regulation and in the Draft MFF Regulation. Application of the conditionality mechanism may thus relatively easily result not in the suspension, but in the permanent loss of EU funds by the Member States. ${ }^{85}$ This is because these Drafts introduce the ' $n+2$ ' rule which authorizes the Commission to enter into the EU budget only the amounts corresponding to the amounts suspended under the conditionality mechanism which were lifted within 2 years (year 'n' +2 ) from the year they were suspended (year ' $n$ '). After the elapse of these 2 years, the Commission will have no legal basis to enter these amounts into the EU budget anymore. From year ' $n$ ' +3 these amounts would be entered into the Union Reserve and could be allocated to the Member States-all Member States, not only the one on which the conditionality mechanism was applied and spend in the MFF 2021-2027.

\footnotetext{
${ }^{81}$ Article 6 (3) Draft Regulation (Commission proposal).

${ }^{82}$ Proposal for a Council Regulation laying down the multiannual financial framework for the years 2021 to 2027 (COM(2018) 322 final).

${ }^{83}$ Article 6 (3) Draft Regulation (Commission proposal).

${ }^{84}$ Article 12 Draft MFF Regulation.

${ }^{85}$ Para. 8 ECA opinion No $1 / 2018$.
} 
This indicates that a Member State whose EU funds were suspended under the conditionality mechanism practically has 2 years from the year of suspension (year ' $n$ ') to remedy the generalised deficiency as regards the rule of law and to request the EU institutions to lift the suspension and re-enter the amounts corresponding to the suspended commitments to the EU budget. ${ }^{86}$ If the Member State fails to undertake these actions during the 2-year period, it loses the possibility to benefit from the suspended EU funds. Conducting all these actions within 2 years can be extremely difficult, taking into account that the elimination of rule of law breaches is usually time-consuming and in addition further time is needed to complete the proceedings in the EU institutions to lift the suspension.

\subsection{Impact of the Conditionality Mechanism on the Beneficiaries of $\mathrm{EU}$ Funds}

In principle, the conditionality mechanism should solely affect those Member States breaching the rule of law, and the consequences of the suspension of EU funds should not in any way influence the beneficiaries of these funds (e.g. farmers, entrepreneurs). ${ }^{87}$ To achieve this objective, the Commission foresees, in the Draft Regulation, that unless the decision adopting the measures imposed under the conditionality mechanism provides otherwise, its adoption does not affect the obligation of the Member States to implement the programme or fund those affected by the measures, and in particular the obligation to make payments to the beneficiaries of EU funds (hereafter: beneficiaries). ${ }^{88}$ In other words, despite the fact that the regular transfer of the EU funds from the EU budget to Member States' budget is suspended under the conditionality mechanism, this State is nevertheless obliged to continue to implement programmes financed from these funds and make payments to beneficiaries. It could be assumed that since the Commission recognized the need to protect the beneficiaries against the possibility that Member States will cease to make payments to them due to the suspension of EU funds under the conditionality mechanism, it should also specify in the Draft Regulation legal measures that beneficiaries could apply against the Member States if this should occur. However, the Commission has not done so. ${ }^{89}$

\footnotetext{
${ }^{86}$ Article 6 Draft Regulation (Commission proposal).

${ }^{87}$ The European Parliament formulated this assumption in its resolution of 14 March 2018 on the MFF (2017/2052(INI)). The Commission also pointed out that beneficiaries of EU funding must not be affected by breaches of the rule of law by Member States. See page 2 of the Draft Regulation.

${ }^{88}$ Article 4 (2) Draft Regulation (Commission proposal).

${ }^{89}$ See critics: ECA opinion No 1/2018, point 27.
} 
The European Parliament has tried to remedy this deficiency and strengthen the legal protection of beneficiaries against the misconduct of Member States. ${ }^{90}$ It proposed that the Commission should provide information and guidance via a website or internet portal for beneficiaries on the obligations of Member States to implement the programme, in particular to make payments to them. The Commission should also provide, on the same website or portal, adequate tools allowing beneficiaries to inform it of any breaches of these obligations by the Member States. The information provided by the beneficiaries may only be taken into account by the Commission if it is accompanied by a proof that they have lodged a complaint to the competent national authority. Beneficiaries informing the Commission would be protected under the proposed Directive on whistle-blower protection. ${ }^{91}$

The above-mentioned rules establish communication channels between the Commission and beneficiaries enabling them to exchange information on any eventual negative effects experienced by the latter due to Member States stopping to make the payments of EU funds. It is, however, doubtful whether such communication itself may effectively protect beneficiaries, without being accompanied by any formal legal actions. Three solutions appear to exist. Firstly, beneficiaries could apply legal remedies established under the national law to claim continuation of payments of EU funds from national authorities. This may however be challengeable or even unattainable in Member States in which an illiberal democracy has captured the national administration and independent prosecution and judiciary. Secondly, the beneficiaries could initiate an action for damages against the Member State claiming the State has infringed its obligation under the Draft Regulation to make payments of EU funds (Francovich liability). The success of this claim may still however depend on the effectiveness and independence of the national judiciary, which could and is troublesome in the case of some Member States. The Commission's legal position is more meaningful, as it could - as a third solution —initiate a general infringement action (Article 258 TFEU) against a Member State who breaches the Draft Regulation by ceasing to make the payments of EU funds to beneficiaries.

It is important to note that the Draft Regulation has equipped the Commission with competences that may help to ensure that beneficiaries would receive their EU funds if its transfer would be suspended on a national level. These competences depend on the method under which the EU budget is implemented (see Sect. 4). Two possibilities exist in this respect, since these EU funds may be spent under indirect management ${ }^{92}$ - by public and private law Member States' organisations - or under shared management ${ }^{93}$ - by Member States, mostly for implementation of CAP and the cohesion policy. If EU funds are spent under indirect management (by public and

\footnotetext{
${ }^{90}$ Recital 14 preamble and Article 4 (3) (a) and (3) (b) Draft Regulation (European Parliament proposal).

${ }^{91}$ Proposal for a Directive on the protection of persons reporting on breaches of Union law COM (2018)218 final.

${ }^{92}$ Article 62 (1) (c) of the Financial Regulation no 2018/1046.

${ }^{93}$ Article 62 (1) (b) of the Financial Regulation no 2018/1046.
} 
private law Member State organisations), the Commission may recover the payments directly made to these organisations for an amount equivalent to the amount not paid to beneficiaries. ${ }^{94}$ When EU funds are spent under shared management (by the Member States), the Commission may impose a financial correction ${ }^{95}$ on them to recover the EU funds from these State. In both cases amounts recovered by the Commission are transferred to the Union Reserve. ${ }^{96}$

These provisions, however, do not change the general rule describe above according to which the Member States are obliged to make payments to beneficiaries despite the transfer of EU funds to these States is suspended under the conditionality mechanism. In other words, suspension of EU funds transferred to a Member State does not change a legal situation of beneficiaries who can claim payments of these funds only from the national administration, not from the Commission.

\subsection{Impact of the Conditionality Mechanism on Relations Between the National Authorities}

Independently of the financial losses that the conditionality mechanism causes to the Member State (Sect. 6.1) and may cause to beneficiaries (Sect. 6.2), it may also affect internal relations within the national administration. More specifically, it may lead to conflicts between the central government of the Member State (the addressee of the EU decision suspending the EU funds) and public authorities functioning on the lower levels in the structure of this State. This is because the Draft Regulation imposes the obligation to make payments to beneficiaries not only on the central government of the Member States, but also on 'government entities', which, as defined, include all public authorities at all levels of government, i.e. national, regional, and local authorities as well as Member State organizations. ${ }^{97}$ It can thus be predicted that if transfers of EU funds would be suspended under the conditionality mechanism, these funds would not be paid to the government of a Member State, whereas the obligation to pay them to beneficiaries would still rest on government entities, e.g. local authorities and national organisations, which are defined broadly. This could easily give rise to internal domestic conflicts.

\footnotetext{
${ }^{94}$ Article 12 draft MFF Regulation.

${ }^{95}$ Article 98 of CP Regulation, COM(2018) 375 final.

${ }^{96}$ Article 12 (2) (a) draft MFF Regulation.

${ }^{97}$ Article 2 (c) Draft Regulation (Commission proposal).
} 


\section{The Conditionality Mechanism and Other Rule-of-Law Mechanisms}

The verification of Member States' compliance with the rule of law that would be performed under the conditionality mechanism if the Draft Regulation is adopted may also be checked under other legal procedures established in EU Treaties. The most important are: the Article 7 TEU procedure and the general infringement procedures (Articles 258-260 TFEU). Since the Draft Regulation does not specify the relationship between the proposed conditionality mechanism and these procedures, this may lead to major legal disputes ${ }^{98}$ and require some clarifications.

\subsection{The Article 7 TEU Procedure}

Article 7 TEU allows the EU institutions to examine whether the Member States respect the values on which the EU is based (Article 2 TEU) which include, inter alia, the rule of law. Article 7 TEU foresees a procedure to be followed and measures to be adopted if a breach of these values is detected. This procedure has already been launched against Poland (in 2017) and Hungary (in 2018).

The Article 7 TEU procedure consists of two stages: 'the preventive stage', where decisions are taken by the Council, ${ }^{99}$ and 'the sanctioning stage', which belongs to the European Council and the Council. ${ }^{100}$ At 'the preventive stage' of the Article 7 TEU procedure, the Council hears the Member State, addresses recommendations to it, and determines whether there is a clear risk of a serious breach by this State of the rule of law. ${ }^{101}$ At 'the sanctioning stage' of the Article 7 TEU procedure, the European Council determines the existence of a serious and persistent breach of the rule of law by this State. ${ }^{102}$ After that, the Council may decide to suspend certain rights of this State deriving from the application of the Treaties, including the voting rights of the representative of the government of this Member State in the Council. ${ }^{103}$ In response to changes in the situation which led to the imposition of the above measures, the Council may decide to alter or revoke them. ${ }^{104}$ As regards the judicial control of actions taken based on Article 7 TEU, the CJEU decides only on

\footnotetext{
${ }^{98}$ Taborowski (2019), pp. 205-207.

${ }^{99}$ Article 7 (1) TEU.

${ }^{100}$ Article 7 (2) and (3) TEU.

${ }^{101}$ The Council acts by a majority of $4 / 5$ of its Members, on a reasoned proposal of $1 / 3$ of the Member States, by the European Parliament or by the Commission, after obtaining the consent of the European Parliament.

${ }^{102}$ In this stage the European Council acts unanimously, on a proposal from $1 / 3$ of the Member States or by the Commission, after obtaining the consent of the European Parliament.

${ }^{103}$ The Council acts by QMV.

${ }^{104}$ The Council acts by QMV.
} 
the legality of the procedural stipulations contained in this Article, ${ }^{105}$ with no substantive control of measures (e.g. sanctions) adopted.

Article 7 (3) TEU, which allows the Council to suspend certain rights of the Member States deriving from the application of the Treaties, deserves a closer look inasmuch as actions undertaken on its basis prima facie may be similar to actions performed under the Draft Regulation. The legal nature of actions undertaken based on Article 7 (3) TEU is not determined by the Treaties. These provisions simply indicate the essence of such actions (suspension of rights deriving from the application of the Treaties) and provide one example (suspension of the voting right in the Council); otherwise they describe such actions by using the neutral term 'measure'. The scope of competences conferred on the Council based on Article 7 (3) TEU have given rise to a heated debate, in which it is commonly accepted that the Council's actions constitute political sanctions imposed on Member States for breaching the values on which the EU is founded. ${ }^{106}$ It should thus be determined whether, based on Article 7 (3) TEU, the Council is authorized to suspend the EU funds of a Member State found to be in breach of the rule of law. In other words, is it true that the competences to be created under the conditionality mechanism (the Draft Regulation) already exist under Article 7 (3) TEU?

Given that under Article 7 (3) TEU the rights of a Member State deriving from the application of the Treaties may be suspended, it should also be possible to suspend transfers of EU funds to this State on this basis. ${ }^{107}$ Undoubtedly, receipt of the EU funds is a right that the Member States benefit from as a result of their EU membership, and the amounts received are set out in the MFF Regulations based on political agreements reached by all Member States. It can therefore be stated that by suspending transfer of the EU funds, the Member State is temporarily deprived of the possibility to enjoy its right deriving from the Treaties.

It thus follows that the suspension of the EU funds of Member States breaching the rule of law is possible both under Article 7 (3) TEU and would be under the conditionality mechanism as well if the Draft Regulation is adopted. It has already been pointed out that the Draft Regulation does not specify the relationship between the Article 7 TEU procedure and the conditionality mechanism. This silence calls for an analysis in which two options should be taken into consideration.

The first option, based on the hierarchy of EU legal norms, is that the Article 7 TEU procedure and the conditionality mechanism are interdependent. The Article 7 TEU procedure (regulated by EU Treaty) has a primary role and the conditionality mechanism (regulated in the Draft Regulation) supplements it. The Article 7 TEU procedure provides a general framework for a suspension of EU funds for breaches of the rule of law, and the Draft Regulation ensures its practical implementation. Based on this reasoning, in legal terms the suspension of EU funds under the conditionality mechanism would constitute a 'measure' within the meaning of

\footnotetext{
${ }^{105}$ Article 269 TFEU.

${ }^{106}$ Geiger (2015), Mangiameli and Saputelli (2013), Besselink (2017) and Dumbrovský (2018).

${ }^{107}$ Taborowski (2019), pp. 194-197.
} 
Article 7 (3) TEU. Following this logic, the suspension of EU funds would have to be first imposed under Article 7 (3) TEU and only then under the conditionality mechanism. In this scenario, however, one breach of the rule of law would be double-checked in two different procedures-first under the Article 7 TEU procedure and then under the conditionality mechanism. At a glance, this seems counterproductive. It may not be also excluded that decisions made under the Article 7 TEU procedure and under the conditionality mechanism would differ, depending on the political ambience, not to mention how unpractical and time-consuming this may be. If one recalls that the reasons to create the conditionality mechanism regulated by the EU secondary law was to overcome the political difficulties or even impossibility of conducting the Article 7 procedure, proven by the unsuccessful proceedings launched against Poland and Hungary, the idea to merge the Article 7 TEU procedure and the conditionality mechanism multiplies existing difficulties. Therefore the second option requires scrutiny.

The second option is based on the argument of procedural effectiveness, or the effet utile principle. Under this option the Article 7 TEU procedure and the conditionality mechanism are parallel and independent of each other, because their legal nature is different. The Article 7 TEU procedure is a political one, while the conditionality mechanism is a legal proceeding. In the Article 7 TEU procedure decisions are made by a political body (the Council) based on political assessments. Judicial control of the legality of these decisions performed by the CJEU is limited only to reviewing the procedural requirements stipulated in Article 7 TEU. This procedure aims exclusively to eliminate breaches of values on which the EU is based, including the rule of law. In contrast, the objective of the conditionality mechanism is more clear-cut, as it should safeguard the EU funds, or more precisely their sound management ${ }^{108}$ and protection ${ }^{109}$ against damages resulting from systematic breaches of the rule of law in the Member State. In this procedure decisions are made based on an assessment of the legal (and not political) criteria established under the Draft Regulation, namely the existence of a generalised deficiency as regards the rule of law in the Member State as defined in this Draft (see Sect. 3.2). The key decisions are taken by the Commission, ${ }^{110}$ which is the guardian of the EU Treaties, ${ }^{111}$ also responsible for the EU budget. ${ }^{112}$ The legality of these decisions is fully checked by the CJEU under an action for annulment. ${ }^{113}$ This kind of jurisdiction of the CJEU significantly strengthens the legal situations of the Member States in comparison to the purely procedural checks of decisions performed by the CJEU under the Article 7 TEU procedure. ${ }^{114}$ In conclusion, it is thus justified to claim the

\footnotetext{
${ }^{108}$ Article 317 TFEU.

${ }^{109}$ Article 325 TFEU.

${ }^{110}$ The European Parliament proposal.

${ }^{111}$ Article 17 TEU.

${ }^{112}$ Article 317 TFEU.

${ }^{113}$ Article 263 TFEU.

${ }^{114}$ Article 269 TFEU.
} 
Article 7 TEU procedure and the conditionality mechanism are parallel and independent of each other.

One could imagine to attack the Draft Regulation as an illegal circumvention of the Article 7 TEU procedures. However, Article 7 TEU does not contain an explicit statement as to whether other Union institutions may defend European values using other instruments. Thus, the general rules apply. It is well established that a specific procedure designed to deal with a certain problem does not exclude developing other instruments, ${ }^{115}$ a core doctrine since the Van Gend en Loos judgment. ${ }^{116}$ Accordingly, it is, in principle, admissible to develop new instruments, ${ }^{117}$ such as the Commission's Rule of Law Framework, or to use the budget to defend European values.

\subsection{The General Infringement Procedure (Arts. 258-260 TFEU)}

The general infringement procedure is another legal proceeding that can be initiated against a Member State's breaching the rule of law. Under this procedure, if the Commission considers that a Member State has failed to fulfil its obligation under the Treaties it may bring the matter before the CJEU. If the CJEU finds that the Member State indeed infringed provisions of EU law, it confirms its finding in a judgment. ${ }^{118}$ The Member State is then obliged to eliminate the infringement found, and if it does not do so the CJEU may impose financial penalties on this State. ${ }^{119}$

The possibilities offered by the general infringement procedure (Article 258-260 TFEU) in the context of rule of law breaches have already been described by legal scholars. ${ }^{120}$ Unlike the Article 7 TEU procedure fruitlessly conducted against Poland and Hungary, the general infringement procedure has already been successfully completed in 2019 in cases against Poland. In case C-192/18 Commission $v$. Poland the CJEU ruled that by establishing a different retirement age for men and women judges and prosecutors in Poland, Poland has failed to fulfil its obligations under Article 157 TFEU and Articles 5(a) and 9(1)(f) of Anti-Discrimination Directive 2006/54/EC. In addition, by granting the Minister for Justice the right to authorise judges to continue to carry out their duties beyond the new retirement age, Poland has failed to fulfil its obligations under Article 19 (1) TEU. ${ }^{121}$ In similar cases C-619/18 Commission v. Poland the CJEU also ruled that Poland had failed to fulfil

\footnotetext{
${ }^{115}$ Bast (2006), pp. 60-63.

${ }^{116}$ CJEU, Case C-26/62, Van Gend en Loos, ECLI:EU:C:1963:1, para. 26.

${ }^{117}$ Bast (2006), pp. 42-67.

${ }^{118}$ Article 258 TFEU.

${ }^{119}$ Article 260 TFEU.

${ }^{120}$ Wennerås (2017), Gormley (2018), Schmidt and Bogdanowicz (2018) and Taborowski (2019).

${ }^{121}$ CJEU Cases C-192/18, Commission v. Poland, ECLI:EU:C:2019:924.
} 
its obligations under Article 19 (1) TEU by lowering the retirement age of the judges of the Supreme Court and by granting the President of Poland the discretion to extend the period of their judicial activity beyond the newly fixed retirement age. ${ }^{122}$ In 2019 the Commission brought another case against Poland (C-791/19 Commission v. Poland) concerning disciplinary proceedings against judges also with charges of breaching Article 19 (1) TEU. Although the charge of breaching the rule of law was not explicitly raised in that case, it concerned judicial independence, which is a key element of the rule of law. ${ }^{123}$

All in all, the general infringement procedure (Article 258-260 TFEU) and the conditionality mechanism (Draft Regulation) are initiated by the Commission against Member States in cases of possible breaches of the EU law, with a view toward eliminating them. However, these procedures significantly differ.

While the general infringement procedure is regulated by EU primary law (Arts. 258-260 TFEU), the conditionality mechanism will be regulated by EU secondary law (the Draft Regulation). Litigation is also resolved differently. In the case of the general infringement procedure, the dispute between the Commission who brings charges and the accused Member State is resolved by the CJEU. Under the conditionality mechanism, the CJEU is involved only if a Member State-an addressee of a decision launching the conditionality mechanism-challenges its legality in the front of the CJEU under action for annulment (Articles 263 TFEU).

Last but not least, while the general infringement procedure is of a horizontal nature, as it may concern all different kinds of violations of EU law (including breaches of the rule of law), the conditionality mechanism is of a sectoral nature, since its concerns only one specific EU law violation, namely a breach of the rule of law detrimental to EU funds. The relationship between the general infringement procedure (Articles 258-260 TFEU) and the sectoral procedures provided in EU regulations allowing the Commission to protect the EU funds has already been analysed by the CJEU. In cases concerning EU funds, the Member States have claimed that if the Commission finds that expenditures financed by EU funds were incurred in breach of EU law, it should initiate the general infringement procedure against them (Article 258 TFEU), under which the CJEU would assess the charges and legality of EU expenditures. By this approach the Member States opposed the Commission's practice to initiate, in such cases, 'the clearance of accounts procedure', regulated in the CAP regulations. In these procedures, now already also conducted in the cohesion policy, if the Commission detects irregular EU expenditures incurred in a Member State, it adopts a decision imposing financial corrections on said State, which obliges it to return the irregularly spent EU funds to the EU budget. The CJEU did not share the Member States' argumentation and ruled that infringements of EU law related to the illegal spending of EU funds should be decided within the framework of sectoral procedures and not under the general

\footnotetext{
${ }^{122}$ CJEU Cases C-619/18, Commission v. Poland, ECLI:EU:C:2019:53, see: Wyrzykowski (2018), Waelbroeck and Oliver (2018), Kmieciak (2019) and Klatt (2019).

${ }^{123}$ Bárd and Ballegooij van (2018).
} 
infringement procedure (Article 258 TFEU). ${ }^{124}$ The practice of bringing cases involving the irregular spending of EU funds under sectoral procedures, developed in, e.g., agriculture and cohesion regulations, is currently applied today. In such cases the Commission does not bring general infringement proceedings against the Member States (Arts. 258-260 TFEU) but applies procedures established under EU secondary law regulations. The question that can be asked is whether the abovementioned case-law of the CJEU would apply to the conditionality mechanism. Prima facie there are no legal obstacles excluding such a possibility.

\section{Conclusions}

Analyses of rule of law instruments established under EU law, analysed in this chapter, lead to the following conclusions.

Practice of conducting the Article 7 TEU procedure-the main EU Treaties procedure aimed to protect the 'European values', including the rule of law (Article 2 TEU) is disappointing. After few years from initiating it against Poland (in 2017) and Hungary (in 2018) there is hardly any real progress made. With more success the general infringement procedure is conducted (Article 258-260 TFEU) - in 2019 two cases were settled by the CJEU (C-192/18 Commission v. Poland and C-619/18 Commission v. Poland) and one case was brought (C-791/19 Commission v. Poland), all concerning capturing judicial independence of Polish courts. For some (unknown) reasons, the possibilities offered by the EU secondary law, namely the CP Regulation on the EU funds, allowing for the suspension and recovery of the EU funds from the Member State infringing EU law, have not been tested yet by the Commission. Instead the Draft Regulation establishing the conditionality mechanism allowing for the suspension of EU funds transferred to the Member State breaching the rule of law (commented on in this chapter) was put on the table. Scrutiny of this Draft lead to the following conclusions. Two most important remarks concern legality of (1) (too) generally formulated premises for applying of the conditionality mechanism and unknown shape of measures to be imposed under this mechanism and (2) launching this mechanism by the Council by the reverse QMV.

First of all, premises for applying the conditionality mechanism were set out extremely broadly, to the extent that their exact meaning and scope is extremely difficult to determine (see Sect. 3.2). Their very essence is 'a generalised deficiency as regards the rule of law' defined as widespread or recurrent practice of public authorities which violates the rule of law and affects or risk affecting the EU fundstheir sound financial management (Article 317 TFEU) or the protection (Article

\footnotetext{
${ }^{124}$ CJEU Cases: 15 and 16-76, France v. Commission, ECLI:EU:C:1979:29, paras 22-35, C-247/ 98, Greece v. Commission, ECLI:EU:C:2001:4, paras 13-14; C-332/00, Greece v. Commission, ECLI:EU:C:2002:235, para. 46.
} 
325 TFEU). To make this abstract notion of a 'generalised deficiency' more pragmatic, the Draft Regulation provided some of their examples. This list contains, on the one hand, such explicit infringements as e.g. ineffective and late cooperation of national authorities with OLAF and EPP; or breaches of confidentiality of communication between lawyers and clients. On the other hand, the list also contains very general breaches, e.g. limiting the effective investigation, prosecution and sanctioning of breaches of EU law; jeopardizing judicial independence; or endangering capacity of the Member State to respect the obligations of EU membership, including the capacity to effectively implement EU law. Instead of legal certainty, this list creates further legal confusion. This lack of precision in formulation of premises to apply the conditionality mechanism is problematic, if one takes into account that the CJEU consequently requires that the principle of legal certainty should be respected particularly rigorously in the case of sanctions and provisions having financial implications. It is clear that the Draft Regulation establishing conditionality mechanism consists of sanctions that would have a financial impact on the Member States breaching the rule of law. This is its essence and raison d'être. Therefore, it can be claimed that excessively general phrasing of premises necessary to launch the conditionality mechanism frustrates the principle of legal certainty.

The same can be said about specific measures (e.g. suspension of EU funds, their recovery) to be imposed under the conditionality mechanism (see Sect. 4). These measures are not regulated by the Draft Regulation, but under EU sectoral Regulations that would establish EU spending rules to be applied in MFF 2021-2027 in specific EU policies (e.g. agricultural, cohesion). Since these Regulations are presently under EU legislative processes run independently from legislative works on the Draft Regulation, the final outcome and impact of the conditionality mechanism, depended on this sectoral rules, cannot be presently assessed. Surprisingly, the Draft Regulation does not mention such reference. What's striking, in the legal debate on the conditionality mechanism a legal relation between the EU sectoral Regulations and the Draft Regulation is often missed with the effect that the conditionality mechanism is described as the self-regulatory one. This is an evident omission.

Secondly, serious legal doubts concern peculiar procedure of adoption of a decision launching the conditionality mechanism. This decision is not adopted under the standard procedure and vote cast established by the EU Treaties but under the specific procedures provided by the Draft Regulation in which the Council votes by the reverse QMV. A proposal of a decision launching a conditionality mechanism submitted by the Commission is adopted unless the Council rejects it within 1 month or otherwise amend it by ordinary QMV. This procedure places the Commission in a privileged position and facilitates the adoption of decisions. If the Council is unable to obtain ordinary QMV to reject the decision (within a month), the Commission's proposal would become a legally binding decision. After 1 month the decision may be however changed, if the Council votes on it by ordinary QMV. At this point in time, it is difficult to definitively assess the legality of this procedure, given the fact that the CJEU has not expressed its view on legality of voting by the Council by reverse QMV. Establishing the legislative procedure and vote cast remaining outside the EU Treaties toolbox may, however, raise serious legal 
concerns. To conclude this part, there is a strong evidence in the above-mentioned parts of the Draft Regulations concerning (1) premises for applying the conditionality mechanism and measures to be imposed under it as well as (2) voting by the Council by the reverse QMV to initiate this mechanism violates the EU Treaty. Despite these reservations, other provisions of the Draft Regulation can also be critically assessed.

Despite the common narration that the conditionality mechanism should only lead to suspension of EU funds, it is clearly regulated in the Draft Regulation that a Member State whose EU funds were suspended under the conditionality mechanism can easily lose them forever (see Sect. 6.1). This will happen if, within 2 years from the year of their suspension, this State will not remedy the breach of the rule of law and convince the EU institution to lift (or alter) the suspension. In such a case the Commission would not be authorised to re-enter the suspended amounts in the EU budget. Because of this serious and automatic effect, the conditionality mechanism may turn out to be a far more severe and detrimental financial penalty than perhaps is envisioned. For this reason formulating precise premises for the adoption of the conditionality mechanism, as stated above, is even more important.

The Draft Regulation provides beneficiaries of EU funds with a weak legal protection if the Member States whose EU funds were suspended under the conditionality mechanism stop making payments to them (see Sect. 6.2). The E-communication channel foreseen would rather not suffice. Thus in effect the real financial impact of suspension in some cases may be passed on beneficiaries. Then the most effective legal remedy they could undertake would probably be an action for damages brought against a Member State breaching the EU law (the Francovich liability). From its side, the Commission could bring to the CJEU a general infringement action (Article 258-260 TFEU) against this State.

The Draft Regulation does not specify the relationship between the conditionality mechanism and other EU Treaties procedures (the Article 7 TEU procedure and general infringement procedure under Articles 258-260 TFEU) that may be applied in cases of breaching the rule of law by the Member States (see Sect. 7). There are, prima facie, no legal obstacles to introduce the conditionality mechanism to EU law, as its legal construction (objectives, premises and procedure) significantly differs from the EU Treaties procedures aimed at safeguarding the rule of law. While the Article 7 TEU procedure is political in nature, the general infringement procedure (Articles 258-260 TFEU) is aimed at any kind of infringement of EU law. In contrast, the conditionality mechanism is a clear-cut procedure, regulated by the EU secondary law, aimed to safeguard the EU funds from damages resulting from systemic infringements of the rule of law by the Member States. It is mainly in the hands of the Commission, as it is the guardian of the EU Treaties (Article 17 TEU) and also responsible for management of the EU budget (Article 317 TFEU). In case of doubts, any legal disputes arising from the application of the conditionality mechanism are to be settled by the CJEU under the action for annulment (Article 263 TFEU).

To conclude the thoughts concerning the Draft Regulation it can be claimed that the important issue to be tackled during coming legislative works on it would be to 
finding a way to ensure the protection of the rule of law without compromising this rule and other values on which the EU is based.

\section{References}

Atik J (2016) From 'no bailout' to the European stability mechanism. Fordham Int Law J 39 (5):1201

Bárd P, Ballegooij van W (2018) The AG Opinion in the Celmer case: why lack of judicial independence should have been framed as a rule of law issue. https://verfassungsblog.de/theag-opinion-in-the-celmer-case-why-lack-of-judicial-independence-should-have-been-framedas-a-rule-of-law-issue/

Bartels L (2005) Human rights conditionality in the EU's international agreements. Oxford University Press, Oxford

Bast J (2006) Grundbegriffe der Handlungsformen der EU. Springer, Heidelberg

Besselink L (2017) The bite, the bark and the howl: Art. 7 TEU and the rule of law initiatives. In: Jakab A, Kochenov D (eds) The enforcement of EU law and values, ensuring member states' compliance. Oxford University Press, Oxford, pp 128-144

Butler I (2018) Two proposals to promote and protect European values through the multiannual financial framework: conditionality of EU funds and a financial instrument to support NGOs. Liberties, 7.03.2018, https://www.liberties.eu/en/news/european-vaues-fund-two-proposals$\mathrm{mff} / 14471$

Chalmers D, Davies G, Monti G (2015) European Union Law: text and materials. Cambridge University Press, Cambridge

Closa C, Kochenov D (2016) Reinforcing rule of law oversight in the European Union. Cambridge University Press, Cambridge

Cornelius J (2016) The European Union development policies are based on European values, democracy, respect for the rule of law and human right. In: Goudappel F, Hirsch B (eds) Democracy and rule of law in the European Union. T.M.C. Asser, The Hague, pp 109-126

Costa M (2017) The accountability gap in EU law. Routledge, London

Craig P (2012) EU administrative law. Oxford University Press, Oxford

Cremona M (2005) EU enlargement: solidarity and conditionality. Eur Law Rev 30(1):19

Dumbrovský T (2018) Beyond voting rights suspension. Tailored sanction as democracy catalyst under Article 7 TEU. In: Hatje A, Tichý L (eds) Liability of member states for the violation of fundamental values of the European Union. Nomos, Baden-Baden, pp 203-228

Fierro E (2003) The EU's approach to human rights conditionality in practice. Martinus Nijhoff Publishers, The Hague

Geiger R (2015) Commentary to Article 7 TEU in: European Union treaties. Commentary. Beck, München

Gormley L (2018) Infringement proceedings. In: Jakab A, Kochenov D (eds) The enforcement of EU law and values, ensuring member states' compliance. Oxford University Press, Oxford, pp $65-78$

Halmai G (2018) The possibility and desirability of economic sanction: the rule of law against the EU Member States. 2018/06, EUI Working Paper Law, http://cadmus.eui.eu/handle/1814/ 51644

Hatje A (2018) Liability of member states for the violation of fundamental values of the European Union. Nomos, Baden-Baden

Hofmann HCH, Rowe GC, Türk AH (2012) Administrative law and policy of the European Union. Oxford University Press, Oxford

Jakab A, Kochenov D (2017) The enforcement of EU law and values: ensuring member states' compliance. Oxford University Press, Oxford 
Kelemen D, Scheppele KL (2018) How to stop funding autocracy in the EU. Verfassungsblog, 10.9.2018, https://verfassungsblog.de/how-to-stop-funding-autocracy-in-the-eu/

Klatt MK (2019) Herabsetzung des Ruhestandsalters für Richter in Polen. Neue Zeitschrift für Verwaltungsrecht 2019:1109-1118

Kmieciak Z (2019) Ochrona tymczasowa w sprawie ze skargi Komisji przeciwko Polsce dotyczącej przepisów ustawy obniżającej wiek przejścia w stan spoczynku sędziów SN. Glosa do postanowienia TSUE z 19.10.2018 r., C-619/18 R. Państwo i Prawo 2019:143-150

Konstadinides T (2017) The rule of law in the European Union. Hart Publishing, Oxford

Louis J-F (2010) The no-bailout clause and rescue packages. Common Market Law Rev 47(4):971

Mangiameli S, Saputelli G (2013) Commentary to Article 7 TEU. In: Blanke H-J, Mangiameli S (eds) The treaty on European Union. Springer, Berlin, p 350

McKenzie L, Meissner K (2017) Human rights conditionality in European Union trade negotiations. J Common Market Stud 55(4):832-849

Pech L, Perju V, Platon S (2019) How to address rule of law backsliding in Romania: the case for an infringement action based on Article 325 TFEU. Verfassungsblog, 2019.5.29, https:// verfassungsblog.de/how-to-adress-rule-of-law-backsliding-inromania, https://doi.org/10. 17176/20190529-121940-0

Peel M, Hopkins V, Shotter J (2019) Finland to push EU budget rule of law clampdown. Financial Times, September 8 2019, https://www.ft.com/content/c3d655fe-cfe7-11e9-99a4-b5ded7a7fe3f

Scheppele KL, Pech L, Kelemen RD (2018) Never missing an opportunity to miss an opportunity: the council legal service opinion on the Commission's EU budget-related rule of law mechanism. Verfassungsblog, 2018.11.12, https://verfassungsblog.de/never-missing-an-opportunityto-miss-an-opportunity-the-council-legal-service-opinion-on-the-commissions-eu-budgetrelated-rule-of-law-mechanism, https://doi.org/10.17176/20181115-215538-0

Schmidt M, Bogdanowicz P (2018) The infringement procedure in the rule of law crisis: how to make effective use of Article 258 TFEU. Common Market Law Rev 55:1061-1100

Schöndorf-Haubold B (2011) Common European administration: the European structural funds. In: Jansen O, Schöndorf-Haubold B (eds) The European composite administration. Intersentia, Antwerp, p 25 et seq

Schroeder W (2016) Strengthening the rule of law in Europe. Hart Publishing, Oxford

Taborowski M (2019) Mechanizm ochrony praworządności państw członkowskich w prawie Unii Europejskiej. Studium przebudzenia systemu ponadnarodowego. Wolters Kluwer, Alphen aan den Rijn

Van Aken W, Artige L (2013) Reverse majority voting in comparative perspective: implications for fiscal governance in the EU. In: de Witte B, Héritier A, Trechsel A (eds) The Euro crisis and the state of European democracy. European University Institute, Fiesole, p 129 et seq

Vita V (2017) Revisiting the dominant discourse on conditionality in the EU: the case of EU spending conditionality. Camb Yearb Eur Legal Stud 19:136

von Bogdandy A (2019) Principles and challenges of a European Doctrine of systemic deficiencies. MPIL Research Paper No. 2019-14, https://ssrn.com/abstract=3431303 or https://doi.org/10. 2139/ssrn.3431303

von Brauneck J (2019) Gefährdung des EU-Haushalts durch rechtsstaatliche Mängel in den Mitgliedstaaten? Europarecht (EuR) 2019:37-60

Waelbroeck M, Oliver P (2018) Enforcing the rule of law in the EU: what can be done about Hungary and Poland? https://blogdroiteuropeen.com/2018/01/31/enforcing-the-rule-of-law-inthe-eu-what-can-be-done-about-hungary-and-poland-par-michel-waelbroeck-et-peter-oliver/

Wennerås P (2017) Making effective use of Article 260 TFEU. In: Jakab A, Kochenov D (eds) The enforcement of EU law and values, ensuring member states' compliance. Oxford University Press, Oxford, pp 79-98 
Wyrzykowski M (2018) Rule of law: European Commission v. Poland. In: Hatje A, Tichý L (eds) Liability of Member States for the violation of fundamental values of the European Union. Nomos, Baden-Baden, pp 169-199

Justyna Lacny is Professor at the Warsaw University of Technology.

Open Access This chapter is licensed under the terms of the Creative Commons Attribution 4.0 International License (http://creativecommons.org/licenses/by/4.0/), which permits use, sharing, adaptation, distribution and reproduction in any medium or format, as long as you give appropriate credit to the original author(s) and the source, provide a link to the Creative Commons license and indicate if changes were made.

The images or other third party material in this chapter are included in the chapter's Creative Commons license, unless indicated otherwise in a credit line to the material. If material is not included in the chapter's Creative Commons license and your intended use is not permitted by statutory regulation or exceeds the permitted use, you will need to obtain permission directly from the copyright holder. 